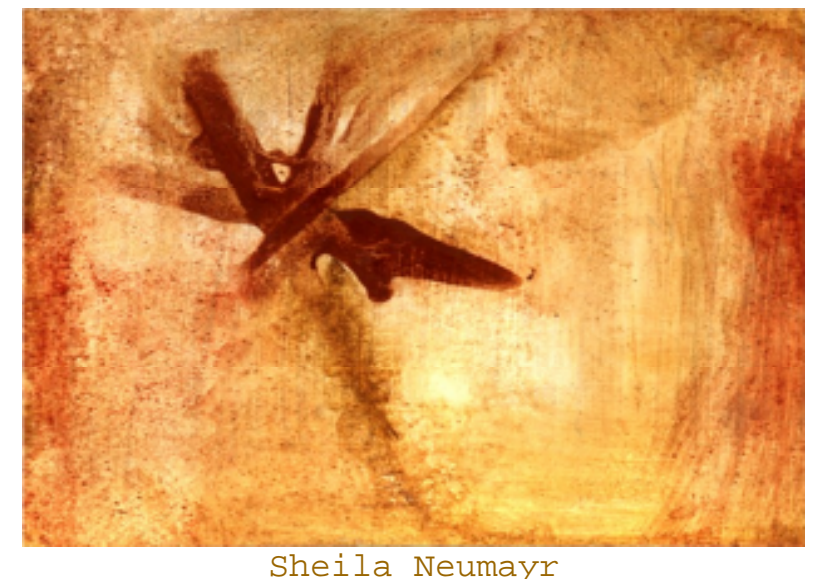

\title{
Panis et laboris
}

\section{Sheila Neumayr}

\author{
Se agora é assim \\ Dentro em pouco é assado, \\ cozido, fresco, \\ ou então refogado. \\ Temperado, sovado, \\ enrolado, fervido, \\ dormido, espremido, \\ servido, comido. \\ Desejado, digerido, \\ ressecado, talhado, \\ semeado, crescido, \\ colhido a centavo. \\ Chorado, louvado, \\ esperado, fundido, \\ pensado, prensado, \\ amassado, mordido. \\ Escolhido, lavado \\ picado, ralado. \\ Levado, enlevado. \\ Engolido.
}

